\title{
Mineral Contents of Indonesian Seaweeds and Mineral Solubility Affected by Basic Cooking
}

\author{
Joko Santoso ${ }^{1}$, Satoko GunjI ${ }^{2}$, Yumiko Yoshie-Stark ${ }^{2 *}$ and Takeshi Suzuki ${ }^{2}$ \\ ${ }^{1}$ Department of Fisheries Processing Technology, Faculty of Fisheries and Marine Sciences, Bogor Agricultural University, Campus \\ IPB Darmaga, Bogor 16680, Indonesia \\ ${ }^{2}$ Department of Food Science and Technology, Faculty of Marine Science, Tokyo University of Marine Science and Technology, \\ Konan, Minato, Tokyo 108-8477, Japan
}

Received June 22, 2005; Accepted February 8, 2006

\begin{abstract}
This experiment was carried out to study the mineral contents and profiles of several Indonesian green, brown, and red seaweeds, and to evaluate the solubilities of $\mathrm{Ca}$ and $\mathrm{Mg}$ as affected by boiling in different solutions (water, $1 \%$ sodium chloride and $0.5 \%$ acetic acid). The macromineral profiles were dominated by $\mathrm{Ca}, \mathrm{K}, \mathrm{Na}$ and $\mathrm{Mg}$. The trace minerals $\mathrm{Cu}, \mathrm{Fe}$ and $\mathrm{Zn}$ were found at low concentrations. Boiling in water and $\mathbf{0 . 5} \%$ acetic acid significantly increased the solubilities of $\mathrm{Ca}$ and $\mathrm{Mg}(\boldsymbol{p}<0.05)$, whereas boiling in $1 \%$ sodium chloride resulted in varying solubilities of $\mathrm{Ca}$ and $\mathrm{Mg}$. Mainly soluble Ca was found in both low $(\mathrm{MW}<10,000)$ and high $(\mathrm{MW}>200,000)$ molecular weight fractions, whereas soluble $\mathrm{Mg}$ was found in the high (MW $>200,000)$ molecular weight fraction.
\end{abstract}

Keywords: Ca, boiling, Indonesia, Mg, mineral, seaweed, solubility, ultrafiltration

\section{Introduction}

From foodstuff standpoint, seaweeds have a long history and even today, they are an important part of the diet of many Asian countries, particularly Japan, China and Korea. Among these three, Japan, where seaweeds (sea vegetables) have a considerable market value, is the most important seaweed consumer (Arasaki and Arasaki, 1983; Nisizawa et al., 1987; Nisizawa, 2002).

Seaweeds are the richest source of minerals (Japan Society for Research of Food Composition, 1985; Ito and Hori, 1989; Ruperez, 2000) and dietary fibers (Suzuki et al., 1993'a Suzuki et al, 1996; Wong and Cheung, 2000; Santoso, Yoshie and Suzuki, 2002). Moreover, seaweeds contain fats and proteins, although at low concentrations (Wong and Cheung, 2001; Sánschez-Machado et al., 2004).

The most common minerals found in seafood including seaweeds are iodine, magnesium, sodium, calcium, phosphorus, iron, potassium, copper and fluorine (Ensminger et al., 1995). Minerals are very important for biochemical reactions in the body as cofactors of enzymes. Mineral deficiency can lead to severe health impairment.

Mineral concentration is only one function of their physiological worth, since they should also be bioavailable. Among functional food components, minerals play an essential role in living a healthy life. Bioavailability is a term used to describe the proportion of a nutrient in food that can be utilized for normal body functions (Watzke, 1998; O’Dell, 1984). For minerals to be bioavailable they should to be in a soluble form, however, not all

* To whom correspondence should be addressed.

E-mail: yumikoy@s.kaiyodai.ac.jp soluble minerals are bioavailable (Clydesdale, 1988). The bioavailability of minerals and trace elements in humans is best studied using an in vivo model; however, experiments using such a model are often complex, timeconsuming and costly, and yield nonreproducible results. The first steps in the study of mineral bioavailability are to measure the concentrations of minerals in foodstuff, in the form in which they exist, as well as the solubility of these minerals.

There are few reports on the mineral content of seaweeds. Studies of minerals in seaweeds mainly focused on sub-tropical and temperate seaweeds such as Japanese seaweeds (Ito and Hori, 1989; Yoshie et al., 1994; Yoshie et al., 1999), Korean seaweeds (Yoshie et al., 1993), and Spanish seaweeds (Ruperez, 2000). There is little information available on mineral compounds in tropical seaweeds, including those in Indonesia.

Since there is no information or data available yet on the mineral profile of Indonesian seaweeds, it is a fertile area for research. Compared to their availability, seaweeds still have a low worldwide consumption and are consumed only in local areas. Seaweed utilization at present is limited to a few genera such as Gracilaria, Gellidium, Eucheuma, Turbinaria, and Sargassum. Almost all collected seaweeds are exported as raw materials for industry. They are unprocessed materials in dry form. Therefore the first objective of the research is to measure the mineral profiles and contents of several Indonesian seaweeds.

Almost all seaweeds are eaten cooked except for the ones used in salads. The most common method of cooking seaweeds is boiling, where sodium chloride or acetic 
acid is usually added as seasonings. Therefore, the second objective of this experiment is to evaluate the effects of boiling in different solutions (i.e., water, sodium chloride and acetic acid) on the solubilities of minerals (i.e., calcium and magnesium) in several Indonesian seaweeds.

\section{Materials and Methods}

Materials Eight species of Indonesian seaweeds were used in this experiment: five green algae (Caulerpa racemosa, Caulerpa sertularioides, Cladophoropsis vauchaeriaeformis and Ulva reticulata), three brown algae (Padina australis, Sargassum polycystum and Turbinaria conoides), and one red alga (Kappaphycus alvarezii), all collected from the Seribu Islands, Jakarta Province.

Sample preparation After removing sand, the seaweed samples were washed with clean seawater and transported to the laboratory under refrigeration. The samples were washed with tap water, wiped with paper towels, then minced with a food processor (MK-K75; Matsushita Electric Corp., Osaka, Japan), and stored at $-20^{\circ} \mathrm{C}$ until use.

Proximate analysis and dietary fiber analysis Moisture, ash and protein contents were determined according to the AOAC method (Association of Official Analytical Chemist, 1990). Dietary fiber content was determined according to an enzymatic-gravimetric method (Prosky et al., 1988).

Total minerals Each sample (2 g wet weight) was weighed in a Kjeldahl flask. Twenty milliliters of concentrated nitric acid was added to each sample and the flask was left to stand overnight. Five milliliters of concentrated perchloric acid and $0.5 \mathrm{~mL}$ of concentrated sulfuric acid were added, and the flask was then heated until no white smoke was emitted. The samples were dissolved in $2 \%$ of hydrochloric acid and transferred into a volumetric flask, then analyzed using an atomic absorption spectrophotometer (Model AA-600, Shimadzu Co., Kyoto, Japan) with acetylene flame, a single-slot head, and a Pt-Rh corrosion resistant nebulizer for measuring the total magnesium $(\mathrm{Mg})$, calcium $(\mathrm{Ca})$, potassium $(\mathrm{K})$ and sodium $(\mathrm{Na})$ contents. Copper $(\mathrm{Cu})$, zinc $(\mathrm{Zn})$ and iron (Fe) contents were measured using an inductively coupled argon plasma emission spectrometer (ICP Nippon Jarrel-Ash ICAP-757V, Kyoto, Japan).

All the reagents used were of analytical grade and their solutions were prepared using double-distilled deionized water. All the glassware and plastic bottles used were dipped in 2\% Contaminon-L (Wako Pure Chemical Industries, Ltd., Osaka, Japan) for at least $2 \mathrm{~h}$, and then rinsed with double-distilled deionized water to remove contaminants.

Soluble minerals The samples $(10 \mathrm{~g})$ were blended in a tube with water or $1 \%$ sodium chloride or $0.5 \%$ acetic acid $(40 \mathrm{~mL})$ at 5,000-10,000 rpm for $2 \mathrm{~min}$ using a blender (Ultra-Turrax T-25; Janke and Kunkel, IKA-Labortechnik, GmbH Co., Staufen, Germany) to produce a watersoluble fraction (0-min-treated sample). The tubes were then boiled in a water bath (Eyela Uni Thermo Shaker
NTS-3000, Tokyo Rikakikai Co., Ltd., Japan) at $100^{\circ} \mathrm{C}$ for 20 min (20-min-treated sample). Next, the samples were centrifuged at $10,000 \mathrm{xg}, 2^{\circ} \mathrm{C}$ for $10 \mathrm{~min}$, and filtered through an Advantec filter paper No. 101 (Toyo Roshi Kaisha, Ltd., Tokyo, Japan). Nonboiled samples were directly centrifuged and filtered. The mineral concentration of the filtrate was measured using an atomic absorption spectrophotometer (Model AA-600, Shimadzu Co., Kyoto, Japan) and calculated as percentage relative the total mineral content. The boiling conditions of $100^{\circ} \mathrm{C}$ for 20 min were chosen in accordance with the previous method of Suzuki et al. (2000). The solubility of each mineral was calculated using Solubility $(\%)=($ Soluble mineral $\mathrm{mg} / \mathrm{g}) /($ Total mineral $\mathrm{mg} / \mathrm{g}) \times 100$.

Soluble minerals fractionated by molecular weight The filtered supernatant $(2.0 \mathrm{~mL})$ was completely passed through Advantec ultra-filter units USY-10 or USY-200 (Toyo Roshi Co.Ltd., Tokyo, Japan) with MW cut-off 10,000 or 200,000 , respectively to obtain low, mid and high molecular weight fractions of the soluble minerals. The concentration of minerals ( $\mathrm{Ca}$ and $\mathrm{Mg}$ ) in the low $(\mathrm{MW}<$ $10,000)$, mid ( $\mathrm{MW}=10,000-200,000)$, and high $(\mathrm{MW}>200,000)$ molecular weight fractions were measured using an atomic absorption spectrophotometer (Model AA-600, Shimadzu Co., Kyoto, Japan), and the results were expressed as percentage of the soluble mineral fraction (MW $<10,000, \mathrm{MW}=10,000-200,000$ and $\mathrm{MW}>200,000)$ relative to the total soluble mineral content.

Statistical analysis All experiments were performed in 3-5 replicates. Results are expressed as mean \pm standard deviation $(n=3-5)$. ANOVA was used to calculate the significance of differences using $p<0.05$.

\section{Results and Discussion}

Proximate composition and dietary fiber content Table 1 shows the moisture, ash, fat, crude protein, and dietary fiber contents in several Indonesian seaweed samples. The samples had ash, protein and dietary fiber contents of 2.1-5.5 g/100 g wet weight, 0.7-3.1 g/100 g wet weight and 7.1-11.6 g/100 g wet weight, respectively. After calculation, the dietary fiber and ash contents per $100 \mathrm{~g}$ dry matter samples were shown to be high.

Mineral composition Table 2 shows the macromineral profiles and contents of the several Indonesian seaweed samples. High $\mathrm{Na}$ concentrations were found in Ulva reticulata $(26.4 \mathrm{mg} / \mathrm{g}$ dry weight), Caulerpa sertularioides $(25.7 \mathrm{mg} / \mathrm{g}$ dry weight), and Cladophoropsis vauchaeriaeformis ( $23.9 \mathrm{mg} / \mathrm{g}$ dry weight), whereas high $\mathrm{K}$ concentrations were found in Kappaphycus alvarezii (87.1 $\mathrm{mg} / \mathrm{g}$ dry weight), Turbinaria conoides $(27.9 \mathrm{mg} / \mathrm{g}$ dry weight), and Sargassum polycystum $(17.5 \mathrm{mg} / \mathrm{g}$ dry weight). The ranges of $\mathrm{Ca}$ and $\mathrm{Mg}$ contents were 2.8-28.3 $\mathrm{mg} / \mathrm{g}$ and $2.9-21.5 \mathrm{mg} / \mathrm{g}$ dry weight, respectively. The highest and the lowest $\mathrm{Ca}$ concentrations were found in Padina australis and Kappaphycus alvarezii, respectively. Ulva reticulata contained the highest $\mathrm{Mg}$ content, and Kappaphycus alvarezii contained the lowest Mg content.

The macromineral profiles and contents of the Indonesian seaweed samples were very similar to those of Japa- 
Table 1. Moisture, ash, fat, protein, and dietary fiber contents of several Indonesian seaweed samples ${ }^{\mathrm{a}}$.

\begin{tabular}{lccccc}
\hline \multicolumn{1}{c}{ Seaweed Sample } & Moisture & Ash & Fat & Protein & Dietary fiber \\
\hline Green algae & & & & & \\
Caulerpa racemosa & $88.8 \pm 0.5^{\mathrm{d}}$ & $2.1 \pm 0.2^{\mathrm{a}}$ & $0.5 \pm 0.1^{\mathrm{c}}$ & $1.5 \pm 0.2^{\mathrm{c}}$ & $7.3 \pm 0.5^{\mathrm{cd}}$ \\
$\begin{array}{l}\text { Caulerpa sertularioides } \\
\text { Cladophoropsis }\end{array}$ & $82.4 \pm 0.6^{\mathrm{a}}$ & $2.9 \pm 0.2^{\mathrm{b}}$ & $2.3 \pm 0.1^{\mathrm{e}}$ & $3.1 \pm 0.2^{\mathrm{e}}$ & $10.9 \pm 0.2^{\mathrm{bc}}$ \\
$\begin{array}{l}\text { vaucheriaeformis } \\
\text { Ulva reticulata }\end{array}$ & $84.9 \pm 0.7^{\mathrm{c}}$ & $4.0 \pm 0.1^{\mathrm{d}}$ & $0.5 \pm 0.1^{\mathrm{bc}}$ & $2.5 \pm 0.5^{\mathrm{d}}$ & $7.1 \pm 0.7^{\mathrm{cd}}$ \\
Brown algae & $83.9 \pm 0.3^{\mathrm{bc}}$ & $2.9 \pm 0.1^{\mathrm{b}}$ & $1.2 \pm 0.2^{\mathrm{e}}$ & $1.2 \pm 0.2^{\mathrm{bc}}$ & $10.6 \pm 0.1^{\mathrm{ab}}$ \\
$\begin{array}{l}\text { Padina australis } \\
\text { Sargassum polycystum }\end{array}$ & $84.7 \pm 0.4^{\mathrm{c}}$ & $3.8 \pm 0.3^{\mathrm{d}}$ & $0.3 \pm 0.1^{\mathrm{b}}$ & $0.9 \pm 0.1^{\mathrm{a}}$ & $10.1 \pm 0.1^{\mathrm{cd}}$ \\
$\begin{array}{l}\text { Turbinaria conoides } \\
\text { Red alga }\end{array}$ & $85.1 \pm 0.3^{\mathrm{c}}$ & $2.5 \pm 0.1^{\mathrm{ab}}$ & $0.8 \pm 0.1^{\mathrm{d}}$ & $1.0 \pm 0.1^{\mathrm{ab}}$ & $9.5 \pm 0.5^{\mathrm{c}}$ \\
\hline \begin{tabular}{l} 
Kappaphycus alvarezii \\
\hline
\end{tabular} & $83.3 \pm 0.7^{\mathrm{ab}}$ & $3.4 \pm 0.1^{\mathrm{c}}$ & $0.2 \pm 0.1^{\mathrm{a}}$ & $0.7 \pm 0.1^{\mathrm{a}}$ & $11.6 \pm 0.3^{\mathrm{d}}$ \\
\hline
\end{tabular}

${ }^{\mathrm{a}}$ Data are means of three determinations $\pm \mathrm{SD}(\mathrm{g} / 100 \mathrm{~g}$ wet weight $)$. Means in columns followed by different superscript letters (a-f) are significantly different $(p<0.05)$.

Table 2. Macromineral contents of several Indonesian seaweed samples ${ }^{\mathrm{a}}$.

\begin{tabular}{lcccc}
\hline \multicolumn{1}{c}{ Seaweed Samples } & $\mathrm{Mg}$ & $\mathrm{Ca}$ & $\mathrm{K}$ & $\mathrm{Na}$ \\
\hline Green algae & & & & \\
Caulerpa racemosa & $3.8 \pm 0.3^{\mathrm{a}}$ & $18.5 \pm 5.3^{\mathrm{c}}$ & $3.2 \pm 0.2^{\mathrm{b}}$ & $25.7 \pm 1.2^{\mathrm{c}}$ \\
Caulerpa sertularioides & $3.7 \pm 1.0^{\mathrm{a}}$ & $12.0 \pm 4.4^{\mathrm{b}}$ & $0.3 \pm 0.0^{\mathrm{a}}$ & $0.7 \pm 0.4^{\mathrm{a}}$ \\
Cladophoropsis vaucheriaeformis & $7.1 \pm 0.6^{\mathrm{b}}$ & $22.3 \pm 3.3^{\mathrm{d}}$ & $9.9 \pm 0.4^{\mathrm{c}}$ & $23.9 \pm 1.2^{\mathrm{c}}$ \\
Ulva reticulata & $21.5 \pm 2.8^{\mathrm{c}}$ & $17.9 \pm 5.3^{\mathrm{c}}$ & $12.6 \pm 0.3^{\mathrm{c}}$ & $26.4 \pm 0.8^{\mathrm{c}}$ \\
Brown algae & & & & \\
Padina australis & $4.0 \pm 1.6^{\mathrm{ab}}$ & $28.3 \pm 4.3^{\mathrm{e}}$ & $0.5 \pm 0.2^{\mathrm{a}}$ & $1.0 \pm 0.9^{\mathrm{a}}$ \\
Sargassum polycystum & $5.7 \pm 0.7^{\mathrm{ab}}$ & $18.7 \pm 1.4^{\mathrm{c}}$ & $17.5 \pm 1.4^{\mathrm{d}}$ & $9.7 \pm 1.4^{\mathrm{b}}$ \\
Turbinaria conoides & $5.7 \pm 0.3^{\mathrm{ab}}$ & $14.8 \pm 2.2^{\mathrm{b}}$ & $27.9 \pm 1.1^{\mathrm{e}}$ & $11.5 \pm 0.5^{\mathrm{b}}$ \\
Red alga & & & & \\
Kappaphycus alvarezii & $2.9 \pm 0.3^{\mathrm{a}}$ & $2.8 \pm 0.3^{\mathrm{a}}$ & $87.1 \pm 5.8^{\mathrm{f}}$ & $11.9 \pm 2.5^{\mathrm{c}}$ \\
\hline
\end{tabular}

${ }^{a}$ Data are means of three determinations $\pm \mathrm{SD}(\mathrm{mg} / \mathrm{g}$ dry weight). Means in columns followed by different superscript letters (a-f) are significantly different $(p<0.05)$.

nese and Spanish seaweeds, with $\mathrm{Na}, \mathrm{Ca}, \mathrm{Mg}$ and $\mathrm{K}$ being the major minerals. In the raw Japanese brown alga Laminaria japonica (ma-kombu in Japanese) the $\mathrm{Na}, \mathrm{Ca}$, $\mathrm{Mg}$ and $\mathrm{K}$ contents were 590, 75, 120 and $42 \mathrm{mg} / 100 \mathrm{~g}$ of edible portion (Resources Council, Science and Technology Agency, 1991). In other brown algae (Fucus vesiculosus, Laminaria digitata, and Undaria pinnatifida) and red algae (Chondrus cryspus and Porphyra tennera) grown in Spain, the ranges of $\mathrm{Na}, \mathrm{Ca}, \mathrm{Mg}$ and $\mathrm{K}$ contents were 36.3-70.6, 3.9-10.1, 5.7-11.8, and 31.8-115.8 mg/g dry weight, respectively (Ruperez, 2002). Furthermore, the Ca con- tent of Gracillaria changii grown in Malaysia was $651 \mathrm{mg}$ / $100 \mathrm{~g}$ wet weight (Norziah and Ching, 2000).

The trace-mineral profiles and contents of several Indonesian seaweed samples are presented at Table 3 . The range of $\mathrm{Cu}$ contents was from $0.002 \mathrm{mg} / \mathrm{g}$ dry weight (Sargassum polycystum) to $0.251 \mathrm{mg} / \mathrm{g}$ dry weight (Caulerpa sertularioides). The ranges of $\mathrm{Fe}$ and $\mathrm{Zn}$ contents were $0.041-0.813$ and $0.003-0.227 \mathrm{mg} / \mathrm{g}$ dry weight, respectively. The highest Fe content was found in Caulerpa racemosa, and the highest $\mathrm{Zn}$ content was found in Cladophoropsis vauchaeriaeformis. 
Table 3. Micromineral contents of several Indonesian seaweed samples ${ }^{\mathrm{a}}$.

\begin{tabular}{llll}
\hline Seaweed Samples & $\mathrm{Cu}$ & $\mathrm{Zn}$ & $\mathrm{Fe}$ \\
\hline
\end{tabular}

\section{$\underline{\text { Green algae }}$}

Caulerpa racemosa

Caulerpa sertularioides

Cladophoropsis vaucheriaeformis

Ulva reticulata

$$
\begin{array}{lll}
0.008 \pm 0.003 & 0.010 \pm 0.002 & 0.813 \pm 0.237 \\
0.251 \pm 0.062 & 0.003 \pm 0.000 & 0.041 \pm 0.010 \\
0.227 \pm 0.003 & 0.227 \pm 0.003 & 0.111 \pm 0.056 \\
0.179 \pm 0.001 & 0.017 \pm 0.001 & 0.280 \pm 0.060
\end{array}
$$

Brown algae

Padina australis

$0.005 \pm 0.001 \quad 0.013 \pm 0.003 \quad 0.446 \pm 0.016$

Sargassum polycystum

$0.002 \pm 0.001 \quad 0.004 \pm 0.001 \quad 0.277 \pm 0.214$

Turbinaria conoides

$0.003 \pm 0.001 \quad 0.006 \pm 0.003 \quad 0.062 \pm 0.017$

$\underline{\text { Red alga }}$

Kappaphycus alvarezii

$0.005 \pm 0.000 \quad 0.018 \pm 0.004 \quad 0.070 \pm 0.033$

${ }^{\mathrm{a}}$ Data are means of three determinations $\pm \mathrm{SD}(\mathrm{mg} / \mathrm{g}$ dry weight).

Compared with the Japanese seaweeds Hizikia fusiformis (hijiki in Japanese), Porphyra yezoensis (susabi-nori in Japanese) and Enteromorpha intestinalis (ao-nori in Japanese), the Indonesian seaweed samples had slightly lower $\mathrm{Fe}$ and $\mathrm{Zn}$ contents with ranges of 9.12-54.4 and 0.82-5.24 mg/100 g dry weight, respectively (Yoshie et al., 1999). Furthermore, the Fe and $\mathrm{Zn}$ contents of brown algae (Fucus vesiculosus, Laminaria digitata, and Undaria pinnatifida) and red algae (Chondrus cryspus and Porphyra tennera) grown in Spain were almost the same, with ranges of $0.033-0.103$ and $0.017-0.071 \mathrm{mg} / \mathrm{g}$ dry weight, respectively (Ruperez, 2002). The red alga Gracillaria changii had an Fe content of $95.6 \mathrm{mg} / 100 \mathrm{~g}$ wet weight (Norziah and Ching, 2000).

The dried products of common Japanese seaweeds (Hizikia fusiformis, Porphyra yezoensis, and Undaria pinnatifida) also had low $\mathrm{Cu}$ contents $(0.08-0.62 \mathrm{mg} / 100 \mathrm{~g}$ edible portion, equal to $0.0009-0.007 \mathrm{mg} / \mathrm{g}$ dry weight) (Resources Council, Science and Technology Agency, 2001), and the Spanish brown and red algae had a low $\mathrm{Cu}$ content less than $0.005 \mathrm{mg} / \mathrm{g}$ dry weight (Ruperez, 2002).

The wide range of mineral contents, not found in edible land plants, is associated with factors such as phylum, geographical origin, and seasonal, environmental and physiological variations of the seaweeds (Mabeau and Fluerence, 1993). Mineral content also depends on the type of seaweed processing (Nisizawa et al., 1987; Yoshie et al., 1994) and the mineralization methods used (Fleurence and Le Coeur, 1993).

Solubility of minerals Six species of locally consumed Indonesian seaweeds were selected in order to evaluate the solubilities of $\mathrm{Mg}$ and $\mathrm{Ca}$ as affected by boiling in different solutions: two green algae (Caulerpa racemosa and Ulva reticulata), three brown algae (Padina australis,
Sargassum polycystum and Turbinaria conoides), and one red alga (Kappaphycus alvarezii).

The solubilities of $\mathrm{Ca}$ and $\mathrm{Mg}$ as affected by boiling in different solutions are shown in Figs. 1 and 2, respective1y. Boiling in water or $0.5 \%$ acetic acid at $100^{\circ} \mathrm{C}$ for 20 min significantly increased the solubility of $\mathrm{Ca}$ in all seaweed samples, except for boiling Caulerpa racemosa in $0.5 \%$ acetic acid, which did not show a significant increase. Boiling in 1\% sodium chloride significantly increased Ca solubility in Ulva reticulata, Turbinaria conoides and Kappaphycus alvarezii, whereas it significantly decreased $\mathrm{Ca}$ solubility in the other three seaweed samples. The percentages of soluble $\mathrm{Ca}$ in water after boiling were from $4.7 \%$ (Sargassum polycystum) to $27.9 \%$ (Kappaphycus alvarezii). After boiling in $0.5 \%$ acetic acid, the lowest and the highest Ca solubilities were found in Turbinaria conoides (11.6\%) and Kappaphycus alvarezii (80.2\%), respectively.

$\mathrm{Mg}$ solubility also significantly increased after boiling in water in all the species except Kappaphycus alvarezii. Boiling in $0.5 \%$ acetic acid, significantly increased the $\mathrm{Mg}$ solubility in Ulva reticulata, Sargassum polycystum, Turbinaria conoides and Kappaphycus alvarezii, whereas the increase was not significant in the other seaweed samples. Boiling in $1 \%$ sodium chloride significantly increased $\mathrm{Mg}$ solubility only in Ulva reticulata and Turbinaria conoides; it either had no effect or it decreased Mg solubility in the other seaweed samples..

Suzuki et al. (2000) studied the effect of salt water heating on solubilities of minerals in shellfish. They reported that the percentage of soluble $\mathrm{Mg}$ sometimes increased after heating in water and $1 \%$ sodium chloride, whereas Ca solubility was not significantly affected by heating in either water or sodium chloride solutions. 


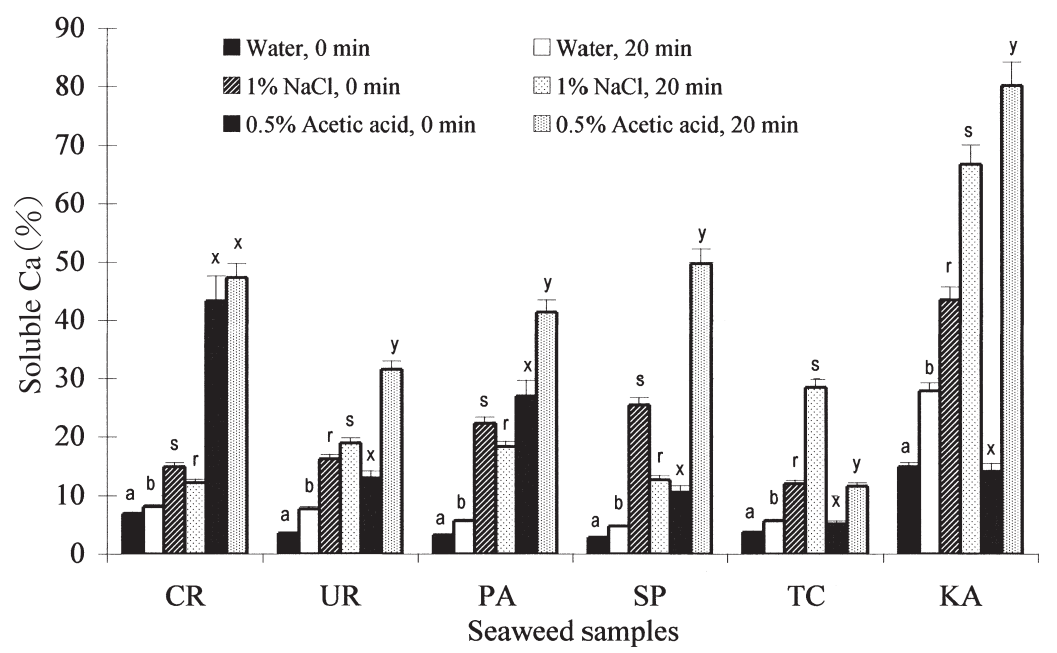

Fig. 1. Percent solubility of calcium as affected by boiling in different solutions.

CR: Caulerpa sertularioides, UR: Ulva reticulata, PA: Padina australis, SP: Sargassum polycystum, TC: Tubinaria conoides, $\mathrm{KA}$ : Kappaphycus alvarezii.

Values in columns followed by the different superscript letters in the same solution ${ }^{\mathrm{a}, \mathrm{b}}$ or $^{\mathrm{r}, \mathrm{s}}{ }^{\text {or }}{ }^{\mathrm{x}, \mathrm{y}}$ are significantly different $(p<0.05)$.

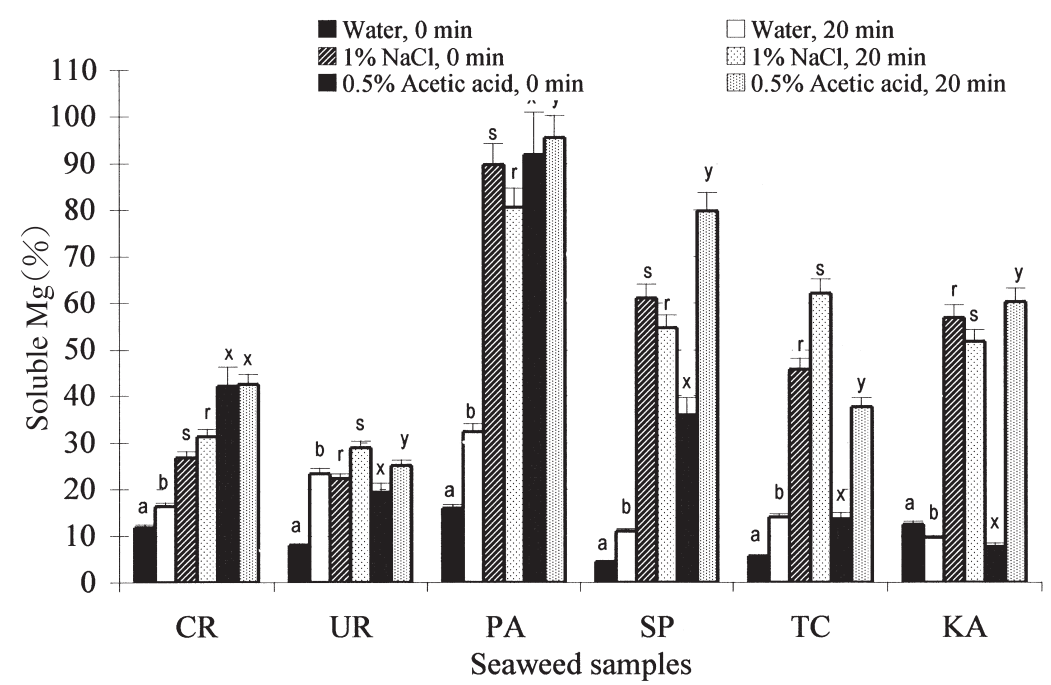

Fig. 2. Percent solubility of magnesium as affected by boiling in different solutions.

CR: Caulerpa sertularioides, UR: Ulva reticulata, PA: Padina australis, SP: Sargassum polycystum, TC: Tubinaria conoides, KA: Kappaphycus alvarezii.

Values in columns followed by the different superscript letters in the same solution ${ }^{\mathrm{a}, \mathrm{b}}$ or $^{\mathrm{r}, \mathrm{s}}$ or $^{\mathrm{x}, \mathrm{y}}$ are significantly different $(p<0.05)$.

These results differ from our findings in Indonesian seaweeds, where the solubility of Ca significantly increases after boiling in water and $0.5 \%$ acetic acid. However, in case of soluble $\mathrm{Mg}$, the results are very similar.

Minerals in food may change their chemical form during and/or after food processing, or interaction with other compounds. Thus their solubilities can increase or decrease depending on the type of processing method. Heating induces the protein denaturation, which may make minerals insoluble. However, since seaweeds have low protein content, the interaction between minerals and proteins may not occur.

Mineral solubility is also influenced by pH. The per- cent solubilities of Fe in three species of Japanese seaweeds Porphyra yezoensis (susabi-nori in Japanese), Enteromorpha intestinalis (ao-nori in Japanese) and Hizikia fusiformis (hijiki in Japanese) at pH 2 were higher than those at pH 6 (Yoshie et al., 1999). The solubilities of $\mathrm{Fe}$ in cod, scallop and prawn decreased with increasing $\mathrm{pH}$ (Yoshie et al., 1997), and the percentage of soluble Fe obtained at an endogenous $\mathrm{pH}$ (2.5-3.1) was higher than that at $\mathrm{pH} 5.5$ in model systems containing organic acids and lignin (Suzuki, et al., 1992). The percentages of soluble $\mathrm{Ca}$ in white wine pomace and apple pomace also increased with decreasing $\mathrm{pH}$ (Torre et al., 1995). Furthermore, Ekhlom et al. (2003) demonstrated that the 


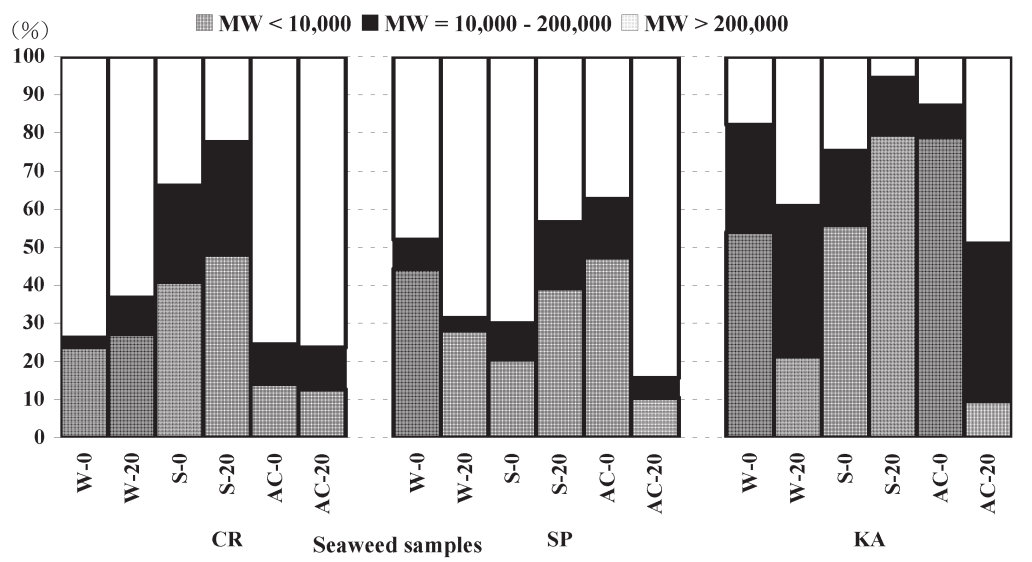

Fig. 3. Molecular weight fraction of soluble calcium as affected by boiling in different solutions. CR: Caulerpa sertularioides, SP: Sargassum polycystum, KA: Kappaphycus alvarezii W-0: Water, 0- min boiling; W-20: Water, 20- min boiling; S-0: 1\% sodium chloride, 0 - min boiling; S-20: 1\% sodium chloride, 20- min boiling; AC-0: 0.5\% acetic acid, 0- min boiling; AC-20: 0.5\% acetic acid, 20- min boiling.

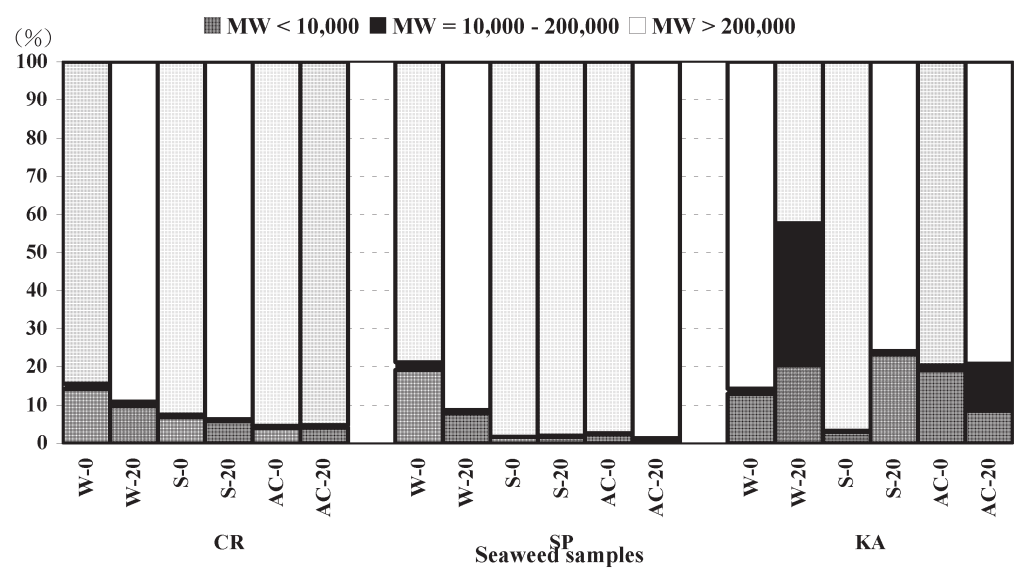

Fig. 4. Molecular weight fraction of soluble magnesium as affected by boiling in different solutions.

CR: Caulerpa sertularioides, SP: Sargassum polycystum, KA: Kappaphycus alvarezii.

W-0: Water, 0- min boiling; W-20: Water, 20- min boiling; S-0: 1\% sodium chloride, 0- min boiling; S-20: 1\% sodium chloride, 20- min boiling; AC-0: 0.5\% acetic acid, 0- min boiling; AC-20: 0.5\% acetic acid, 20- min boiling.

solubilities of $\mathrm{Ca}, \mathrm{Mg}$ and $\mathrm{K}$ in oat bran increased with citric acid concentration. In this study, the solubilities of $\mathrm{Ca}$ and $\mathrm{Mg}$ in Indonesian seaweed samples were also influenced by $\mathrm{pH}$. By heating in $0.5 \%$ acetic acid, the solubilities of $\mathrm{Ca}$ and $\mathrm{Mg}$ increased compared with those in the case of heating in water or $1 \%$ sodium chloride.

Seaweeds contain a high dietary fiber content which is associated with minerals and influences their solubility. Fiber components, such as cellulose, hemicellulose, pectin, other polysaccharides and lignin, may form insoluble complexes with elemental minerals, and thus reduce the bioavailability of these minerals (Ekhlom et al., 2003). In the case of seaweeds, heating was effective for extracting carbohydrates from matrixes and water-soluble dietary fiber content in all seaweeds steadily increased during heating (Suzuki et al., 1993'; Suzuki et al., 1993c).

The soluble dietary fiber contents of Kappaphycus alvarezii and Padina australis were higher than those in the other seaweed samples (Santoso et al., 2002), and solubilities of $\mathrm{Ca}$ and $\mathrm{Mg}$ in both of these seaweeds was expected to increase, particularly after boiling in $0.5 \%$ acetic acid. These results indicate that soluble dietary fibers are enhancers, and thus they could interact with magnesium and calcium and induce increases in their solubility. Clydesdale (1988) defined an enhancer as a molecular species in food that forms a compound with minerals which is soluble and can be absorbed by mucosal cells.

Soluble minerals fractionated by molecular weight Seaweeds contain a large amount of dietary fibers. During boiling dietary fibers can be extracted from matrix, particularly soluble dietary fibers can interact with other components including minerals. The interaction between soluble minerals and soluble dietary fibers produces mineral-dietary fiber complexes in different molecular weight fractions. In this experiment, we separated soluble minerals by molecular weight in three categories: low $(\mathrm{MW}<10,000)$, mid $(\mathrm{MW}=10,000-200,000)$, and high (MW $>200,000)$ molecular weight fractions by ultrafiltration. Three species of Indonesian seaweeds were se- 
lected, namely Caulerpa racemosa, Sargassum polycystum, and Kappaphycus alvarezii, representative of green, brown and read algae groups, respectively.

The solubilities of $\mathrm{Ca}$ and $\mathrm{Mg}$ in the low, mid, and high molecular weight fractions as affected by boiling in different solutions are presented in Figs. 3 and 4, respectively. Boiling in $1 \%$ sodium chloride increased the solubility of $\mathrm{Ca}$ in the low and mid molecular weight fractions, but not in the mid molecular weight fraction in Kappaphycus alvarezii. However, in the high molecular weight fraction (MW > 200,000), its solubility decreased after boiling. The largest decrease was found in Sargassum polycystum followed by Kappaphycus alvarezii, where Ca solubility decreased from 70.0 to $43.4 \%$ and 24.7 to $5.5 \%$, respectively.

Boiling in the other solutions gave various solubilities of $\mathrm{Ca}$ in the low, mid and high molecular weight fractions. Boiling in either water or $0.5 \%$ acetic acid sometimes increased and sometimes decreased Ca solubility. Soluble Ca was mainly in low and high molecular weight fractions. However, in the case of Kappaphycus alvarezii after boiling in water, the Ca solubility was also high $(39.4 \%)$ in the mid molecular weight fraction.

The result suggests that the interaction between soluble $\mathrm{Ca}$ and low and high molecular weight compounds is stronger than that between soluble $\mathrm{Ca}$ and mid molecular weight compounds. Since dietary fibers are the main components of seaweeds, they can interact with other compounds including minerals. These low and high molecular weight fractions of soluble dietary fibers can bind to soluble Ca.

The solubility of Mg in the low, mid, and high molecular weight fractions was varyingly affected by boiling in different solutions and did not show a distinct pattern. More than $75 \%$ soluble $\mathrm{Mg}$ was found in the high molecular weight fraction ( $\mathrm{MW}>200,000$ ), and boiling in $0.5 \%$ acetic acid produced the highest percentage (98.7\%) of soluble Mg in Sargassum polycystum.

The percentages of soluble $\mathrm{Mg}$ in the low molecular weight fractions ranged from 1.6\% (Sargassum polycystum in $1 \%$ sodium chloride, before boiling) to $23.2 \%$ (Kappaphycus alvarezii in 1\% sodium chloride, after boiling), respectively. Generally, a moderate percentage of soluble $\mathrm{Mg}$ in the low molecular weight fraction was found in water without boiling, whereas in the other solutions the percentage was not so high, except in $1 \%$ sodium chloride after boiling and in $0.5 \%$ acetic acid without boiling in Kappaphycus alvarezii.

The percentages of soluble $\mathrm{Mg}$ in the mid molecular weight fraction was low $(\leq 2.0 \%)$, except in Kappaphycus alvarezii after boiling in water $(37.4 \%)$ and $0.5 \%$ acetic acid (12.2\%).

Results obtained by Suzuki et al. (2000) showed that more than $50 \%$ of soluble $\mathrm{Mg}$ in low molecular weight fraction was found in shellfish, and only a low percentage of soluble $\mathrm{Mg}$ was found in the high molecular weight fraction in short-necked and hard clam. Shellfish have high protein and low fiber contents, different from Indonesian seaweeds, which contain a high fiber content and a low protein content (Santoso et al., 2002). This suggests that most soluble $\mathrm{Mg}$ interacts with high molecular weight compounds (i.e., high molecular weight soluble dietary fibers).

From these results, it is concluded that Indonesian seaweeds contain high macromineral (i.e., $\mathrm{Na}, \mathrm{K}, \mathrm{Ca}$ and $\mathrm{Mg}$ ) contents, but low trace-mineral (i.e., $\mathrm{Cu}, \mathrm{Zn}$ and $\mathrm{Fe}$ ) contents. The solubilities of $\mathrm{Ca}$ and $\mathrm{Mg}$ are significantly increased by boiling, particularly in acid solutions $(0.5 \%$ acetic acid).

In this experiment, the sample collection was carried out only in the dry season. Therefore, further research is necessary to precisely determine the effects of different collection or harvest times (i.e., wet season) on the level of minerals including heavy metals as contaminant indicators.

Since people consume food not in a single form but in mixed forms, our study of the interaction between food components and minerals as enhancers or inhibitors is ongoing.

Acknowledgements The authors wish to express their thanks to effort of Mr. Satir for collecting seaweed samples, and to Dr. H. Oba of the Laboratory of Aquaculture, Department of Aquatic Biosciences, Tokyo University of Marine Science and Technology for assistance in identifying the seaweed samples. This study was partly supported by JSPS (Japan Society for the Promotion of Science).

\section{References}

Arasaki, S. and Arasaki, T., 1983. Low calorie, high nutrition, vegetables from the sea, to help you look and feel better. Japan Publication Inc., Tokyo.

Association of Official Analytical Chemist. AOAC. Official methods of Analysis, $15^{\text {th }}$ Ed., AOAC, Arlington, VA, 1990.

Clydesdale, F.M., 1988. Minerals: Their chemistry and fate in food. In: Smith, KT. (ed). Trace Minerals in Foods, (pp. 57-94). Marcel Dekker Inc., New York.

Ekhlom, P., Virkki, L., Ylinen, M. and Johansson, L., 2003. The effect of phytic acid and some natural chelating agents on the solubility of mineral elements in oat bran. Food Chemistry, 80, 165-170.

Ensminger, A.H., Ensminger, M.E., Konlande, J.E. and Robson, J. R.K., 1995. The Concise Encyclopedia of Foods and Nutrition. CRC Press, Boca Raton, Florida.

Fleurence, J. and Le Coeur, C., 1993. Influence of mineralization methods on the determination of the mineral content of brown seaweed Undaria pinnatifida by atomic absorption spectrophotometry. Hydrobiologia, 260/261, 531-534.

Ito, K. and Hori, K., 1989. Seaweed: Chemical composition and potential food uses. Food Reviews International, 5, 101-144.

Japan Society for Research of Food Composition, 1985. Standard Tables of Dietary Fibers, Minerals, Cholesterols, and Fatty Acids in Japan. Ishiyaku Shuppan, Tokyo. Japan.

Mabeau, S. and Fleurence, J., 1993. Seaweed in food products: Biochemical and nutrition aspects. Trends in Food Science and Technology, 4, 103-107.

Nisizawa, K., Noda, H., Kikuchi. R. and Watanabe, T., 1987. The main seaweeds in Japan. Hydrobiologia, 151/152, 5-29.

Nisizawa K., 2002. Seaweeds Kaiso. Bountiful harvest from the seas. Sustenance for health and well being by preventing common life-style related diseases. Japan Seaweed Association. Kochi.

Norziah, M.H. and Ching, C.Y., 2000. Nutritional composition of edible seaweed Gracilaria changgi. Food Chemistry, 68, 69-76.

O'Dell, B.L., 1984. Bioavailability of trace elements. Nutrition 
Review, 42, 301-308.

Prosky, L., Asp, N.G., Schweizer, T.F., DeVries, J.W. and Furda, I. 1998. Determination of insoluble and total dietary fiber in foods and food product: Intercollaborative study. Journal of Association of Official Analytical Chemist, 71, 1017-1023.

Resources Council, Science and Technology Agency, 2001. Standard Tables of Food Composition in Japan $5^{\text {th }}$ Edition. Daiichi Shuppan Publishing Co., Tokyo, Japan.

Resources Council, Science and Technology Agency, 1991. Standard Tables of Food Composition in Japan, Minerals (Magnesium, Zinc and Copper). Resources Council, Science and Technology Agency, Tokyo. Japan.

Ruperez, P., 2000. Mineral content of edible marine seaweeds. Food Chemistry, 79, 23-26.

Sánschez-Machado, D.I., López-Cervantes, J., López-Hernández, J. and Paseiro-Losada, P., 2004. Fatty acids, total lipid, protein and ash contents of processed edible seaweeds. Food Chemistry, 85, 439-444.

Santoso, J., Yoshie, Y. and Suzuki, T., 2002. The distribution and profile of nutrients and catechins of some Indonesian seaweeds. Fisheries Science, 68 (supplement), 1647-1648.

Suzuki, T., Clydesdale, F.M. and Pandolf, T., 1992. Solubility of iron in model containing organic acids and lignin. Journal of Food Protection, 55, 893-898.

Suzuki, T., Nakai, K., Yoshie, Y., Shirai, T. and Hirano, T., 1993a. Digestability of dietary fiber in brown algae, kombu by rats. Nippon Suisan Gakkaishi, 59, 879-884.

Suzuki, T., Nakai, K., Yoshie, Y., Shirai, T. and Hirano, T., 1993 Changes in dietary fiber in seaweed foods during commercial heat processing. Nippon Suisan Gakkaishi, 59, 1371-1375.

Suzuki, T., Yoshie, Y., Shirai, T. and Hirano, T., 1993. Effects of irradiation and heating on extraction of carbohydrates from brown seaweed, Gagome Kjellmaniella crassifolia. Nippon Suisan Gakkaishi, 59, 1593-1597.

Suzuki, T., Ohsugi, Y., Yoshie, T., Shirai, T. and Hirano, T., 1996. Dietary fiber content, water-holding capacity and binding capacity of seaweeds. Fisheries Science, 62, 454-461.

Suzuki, T., Yoshie, Y. and Horii, A., 2000. Solubility of minerals in shellfish by heating with salt water. In: Carman, O., Sulistiono,
Purbayanto, A., Suzuki, T., Watanabe, S., and Arimoto, T. (eds). The Proceeding of the JSPS-DGHE International Symposium on Fisheries Science in Tropical Area (pp. 563-568). TUF International JSPS Project, Tokyo.

Torre, M., Rodriquez, R.A. and Calixto-Saura, F., 1995. Interaction of $\mathrm{Fe}$ (II), $\mathrm{Ca}$ (II) and FE (III) with high dietary fibre materials: A physicochemical approach. Food Chemistry, 54, 23-31.

Watzke, H.J., 1998. Impact of processing on bioavailability examples of minerals in foods. Trends in Food Science and Technology, 8, 320-327.

Wong, K.H. and Cheung, C.K., 2000. Nutritional evaluation of some subtropical red and green seaweeds. Part I - proximate composition, amino acid profiles and some physico-chemical properties. Food Chemistry, 71, 475-482.

Wong, K.H. and Cheung, C.K., 2001. Nutritional evaluation of some subtropical red and green seaweeds. Part II - In vitro protein digestibility and amino acid profiles of protein concentrates. Food Chemistry, 72, 11-17.

Yoshie, Y., Suzuki, T., Shirai, T., Hirano, T. and Lee, E.H., 1993. Dietary fiber, minerals, free amino acids and fatty acid compositions in dried nori of several culture places in Korea. Journal Tokyo University of Fisheries, 80, 197-203.

Yoshie, Y., Suzuki, T., Shirai, T. and Hirano, T., 1994. Changes in the contents of dietary fibers, minerals, free amino acids and fatty acids during processing of dried nori. Nippon Suisan Gakkaishi, 60, 117-123.

Yoshie, Y., Suzuki, T., Shirai, T. and Hirano, T., 1994. Changes in the contents of dietary fibers, minerals, free amino acids and fatty acids during processing of dried nori. Nippon Suisan Gakkaishi, 60, 117-123.

Yoshie, Y., Suzuki, T. and Clydesdale, F.M., 1997. Iron solubility from seafoods with added iron and organic acids under simulated gastrointestinal conditions. Journal of Food Quality, 20, 235-246.

Yoshie, Y., Suzuki, T., Pandolf, T. and Clydesdale, F.M., 1999. Solubility of iron and zinc in selected seafoods under simulated gastrointestinal conditions. Food Science Technology Research, 5, 140-144. 